The University of San Francisco

USF Scholarship: a digital repository @ Gleeson Library |

Geschke Center

Sociology

College of Arts and Sciences

2011

\title{
The Unwatched Life Is Not worth Living: The Elevation of the Ordinary in Celebrity Culture
}

Joshua Gamson

University of San Francisco, gamson@usfca.edu

Follow this and additional works at: http://repository.usfca.edu/soc

Part of the Sociology Commons, and the Television Commons

\section{Recommended Citation}

Gamson, J. (2011). The unwatched life is not worth living: The elevation of the ordinary in celebrity culture. PMLA, 126(4), 1061-1069. doi:10.1632/pmla.2011.126.4.1061

This Article is brought to you for free and open access by the College of Arts and Sciences at USF Scholarship: a digital repository @ Gleeson Library | Geschke Center. It has been accepted for inclusion in Sociology by an authorized administrator of USF Scholarship: a digital repository @ Gleeson

Library | Geschke Center. For more information, please contact repository@usfca.edu. 
WHEN MY FIRST DAUGHTER WAS BORN A FEW YEARS AGO, I ENTERED A

\section{CELEBRITY NEWS BLACKOUT, A SOMEWHAT DISCOMFITING CONDITION}

for a sociologist of celebrity. When she entered preschool, though, I resubscribed to Us Weekly and devoured its morsels like a starving man at McDonald's: Kim Kardashian and her then-boyfriend ate at Chipotle on their first date! Ashton Kutcher was mad about his neighbor's noisy construction! Lindsay Lohan is back in rehab! I felt less disconnected from others, comforted by the familiar company, a little dirtier and a little lighter.

I meandered through online celebrity culture, too, where things were not quite as familiar, visiting mean Internet gossip sites like Gawker and PerezHilton.com and listening to remixes of Christian Bale's foul-mouthed rant at a cameraman. I also watched an array of YouTube celebrities, most of whom had been adopted by fans for some quirk they'd exhibited intentionally or just by living their lives: Tay Zonday, a tiny PhD candidate with a giant singing voice; the jumbo Yosemite dweller whose awed response to a double rainbow was viewed over twenty million times; and Antoine Dodson, whose interview clip from a local news show ("hide your kids, hide your wife, hide your husband, cause they raping everybody out here") was a YouTube sensation, leading to remixes on iTunes, a T-shirt line, a ringtone, and Halloween costumes. Via Twitter, I could receive a barrage of 140-character tidbits from celebrities, such as info about Tina Fey's lunch (Caramello bar), Demi Moore's adoption rumor (false), and her daughter Rumer's highway experience ("Two words: Traffic sucks"). If returning to celebrity culture was a bit like coming home-I'd written a book on the subject, Claims to Fame, back in the 1990s - that home also seemed to have been significantly remodeled.

This essay maps that perplexing architecture, considering how and with what significance twenty-first-century American celebrity culture builds on and departs from earlier forms. ${ }^{1}$ In particular, I highlight what is arguably the most prominent development in American celebrity culture over the past two decades: the decisive turn toward the
The Unwatched Life Is Not Worth Living: The Elevation of the Ordinary in Celebrity Culture

JOSHUA GAMSON
JOSHUA GAMSON, professor of sociology at the University of San Francisco, is the author of Claims to Fame: Celebrity in Contemporary America ( $\mathrm{U}$ of California P, 1994), Freaks Talk Back: Tabloid Talk Shows and Sexual Nonconformity (U of Chicago P, 1998), and The Fabulous Sylvester: The Legend, the Music, the Seventies in San Francisco (Picador-H. Holt, 2005). A recent Guggenheim fellow, he is working on a book about unconventional family creation. 
ordinary. As opposed to earlier periods, when American celebrities were a class of people perceived as extraordinary and treated to extraordinary lives-a "powerless elite," as Francesco Alberoni once called them-celebrity culture is increasingly populated by unexceptional people who have become famous and by stars who have been made ordinary. What are the roots and contours of this cultural transformation? What are we to make of the triumph of the ordinary celebrity, of what Graeme Turner has called the "demotic turn" in celebrity culture (82)?

The tension between the extraordinary and the ordinary in American celebrity culture - and, relatedly, between merit and manufacture, authenticity and fakery-is not new (Gamson, Claims, chs. 1-2; Braudy). Yet the emergence of reality TV and of the Internet, especially Web 2.0 phenomena, has pushed ordinariness into the cultural forefront. In what follows, I document the propulsion of ordinary folks into stardom, the focus on the ordinary lives of famous people, and the rise of new celebrity types. Although it is tempting to interpret these developments as uniformly democratizing, I argue that they are met also with pullbacks toward the centralized celebrity industry and may even reinforce the rarity and value of the "extraordinary" celebrity. In the end, the significance of the ordinary in celebrity culture is found not so much in what it reveals about how fame is differently produced as in its harmony with the increased expectation, and everyday experience, of being watched.

\section{Twentieth-Century Celebrity Culture: Ordinariness as a Persistent Theme}

The analytic categories with which celebrity is best apprehended remain useful even in the midst of change: celebrity culture is at once a commodity system, an industry, a set of stories, and a participatory culture. The commodity at stake is embodied attention; the value of the celebrity inheres in his or her ca- pacity to attract and mobilize attention, which is then typically attached to other products (a television show, a magazine cover, a record album) or sold for cash directly to people making those other products. In its most conventional form, celebrity in the United States emerges from, and is managed by, a tightly controlled, well-resourced industry, linked institutions centered mostly in Los Angeles and New York. From those centers, often in a conflict-ridden negotiation between publicists and journalists (Gamson, Claims, chs. 3-5), the stories of celebrity arise: not just about famous people but about fame as well, about the machinery of publicity, about what is and isn't admirable, about distinguishing the real from the fake, the private self from the publicly presented one. Consumers of celebrity culture then do all sorts of things with these stories, often giving them new meanings. Some make use of celebrity stories to fantasize a different life, to construct their identities, or to model themselves on people they admire or envy; others use them as fodder for connecting socially with one another, by gossiping with impunity about the behavior and relationships of these commonly held figures; still others use the stories to have conversations in which they attempt to distinguish the real person from the mass-produced commodity (Gamson, Claims, chs. 6-8; Turner, pt. 3).

Within this cultural system, which remains very much intact, ordinariness has a long, complex, and vexed history. Some critics have argued that celebrity by definition disconnects exceptionality from fame; in what is perhaps the foundational text of "celebrity studies," Daniel Boorstin argues that celebrities are "human pseudo-events," people who are "well-known for their well-knownness" (67), as opposed to heroes, who were famous for doing great things. As Leo Braudy has amply demonstrated, fame never simply resulted from heroic action; yet one need only look as far as Paris Hilton, or her foremother Zsa Zsa Gabor, to see that the modern celebrity 
system has the wherewithal, incentives, and tendency to value visibility in and of itself. To do its work, the celebrity industry certainly doesn't need its celebrities to be extraordinary. What the celebrity industry does require of its humans is that they live, whether glamorously or not, for the camera. As Neal Gabler suggests, what distinguishes celebrities-most of whom are actually known for something they've done-is narrative: a celebrity stars in his or her own "life movie" and provides entertainment by "the very process of living" (5). In this system, there has long been plenty of room for ordinariness to flourish.

Indeed, the story lines of American celebrity culture have been built on a set of tensions in which ordinariness plays a crucial role. American culture, at least as an ideological environment, is often hostile toward anything resembling aristocracy, which conflicts with egalitarian beliefs. The presence of a celebrity class has thus presented a bit of a problem. Contemporary celebrity has been composed of two major, often competing narratives about the relation between celebrity status and merit. In one, people become famous because of achievement, merit, talent, or special internal qualities, earning admiration and attention; they are cream at the top of a meritocracy. In the other, people become famous because they have been made so, artificially produced for mass consumption by a team of investors, publicists, makeup artists, magazine publishers, and the like; they are factory products. In the first, they are successful because they are extraordinary, unlike us, and more powerful than we are; in the second, they are ordinary people, just like us, only luckier, prettier, and better marketed. In the first, their elevated social status is justified; in the second, arbitrary. In the first, they are to be revered or vicariously consumed; in the second, to be disdained or consumed as objects of identification. ${ }^{2}$

These two stories have coexisted, sometimes uncomfortably, for quite a while. In the days of the Hollywood studio system, where celebrity production was tightly controlled, it was possible to build and maintain images of extraordinariness (deCordova). After its demise, beginning with antitrust actions in the late 1940 s, celebrity production became dispersed among a greater number of interested parties and the control of images and stories more conflict-ridden. Celebrity production also became more visible, heightening the suspicion that celebrity status was artificially produced and undeserved. Here displays of ordinariness quickly took a central place, offering up the "real" self behind the "manufactured" celebrity image, with images of famous people's "everyday lives" as the means to approximate that realness (Gamson, Claims, chs. 1-2).

The most common narrative strategy"come see what they're really like"-invites identification with celebrities. The suggestion that celebrities are ordinary folks offers, in place of cynicism, the fantasy of intimacy with the famous (Dyer; Schickel). Thus, for instance, one often encounters photos that demonstrate simultaneously celebrities' extraordinary glamour and awesome beauty on the red carpet and their just-like-us, unglamorous trips to the grocery store or a restaurant. Gossip columns and tabloids, also widespread since the beginning of modern, twentieth-century celebrity culture and exploding in the 1970s, propose to puncture the public image of celebrities with the often sordid or ugly "truths" of their private lives, their ordinary human foibles, their feet of clay. The supermarket magazine racks declare that, like everyone else, celebrities look plain or blemished without makeup, lie about their sexuality, get fat, betray lovers, go into wild rages; despite their publicists' protestations, they are ordinary mortals. In these ways, as celebrity has become suspect as fabricated and false, the ordinary life has been made to stand in for the real and true. Admiration and resentment, honor and suspicion, egalitarian 
and hierarchical impulses have thus been precariously held together.

\section{Reality TV: The Celebration of the Ordinary}

In 1968 Andy Warhol quipped that "in the future, everyone will be world-famous for fifteen minutes." When that line became tired, he changed it to "In fifteen minutes, everybody will be famous" (Warhol and Colacello 48). Hyperbole was Warhol's trademark, but he wasn't exactly wrong. If ordinariness has been a persistent part of American celebrity discourse for at least a century-in part because it connotes the democratic openness of Warhol's predictions-it seems to have overwhelmed that discourse in the last twentyfive years. Several forces, most notably new television programming strategies and new Web technologies, have pushed the ordinary to the forefront.

So-called reality TV developed in the late 1980 s in response to changing economic conditions in Hollywood characterized, among other things, "by the rising costs of network program production, competition for advertising revenue among more distributors," and "greater debt incurred by the networks" (Collins 96; see also Raphael). Reality programming had several advantages: it was quicker and cheaper to produce than scripted programming, since it needed neither writers nor actors, and it bypassed union constraints and agents' fees, since it used nonunion "actors." As Turner describes it, reality TV producers take control of the "economy of celebrity by turning it into an outcome of a programming strategy" (53). They take "civilians," often with no special abilities or achievements, and, by filming them, make celebrities "out of nothing, bypassing what we might think of as the conventional conditions of entry (specialized training, or a history of performance, for instance)." Given the vast and unending oversupply of ordinary people seeking visibility and reality TV contestants' status as com- modities owned by the production company, these "dispensable celebrities" are cheap and easily replaced (Collins 89). Ordinariness, because of its benefits to producers, is an essential programming strategy.

The making of celebrities out of ordinary folks is not just one of reality TV's chief consequences but also one of its main story lines (Holmes). Consider the main subgenres of reality programming. On reality talent competitions like American Idol, So You Think You Can Dance, and America's Next Top Model, the central narrative is in some ways oldschool: ostensibly, the shows are a means of finding deserving stars and watching as they earn the right to fame. At the same time, the shows' interest comes from observing the process by which ordinary people become celebrities, how they are explicitly transformed, commodified, and marketed-what Tom Mole calls "hypertrophic celebrity" culture, in which fascination is directed at the mechanics of celebrity production. On American Idol, for example, contestants talk openly about how they intend to position themselves within "the industry," and their movement from obscurity to celebrity is dramatized, complete with screaming fans, makeovers, and, not incidentally, weekly roles in Ford ads.

Other reality subgenres dramatize the ordinary becoming celebrated more obliquely but just as powerfully. On reality games like Survivor, The Apprentice, or The Bachelor, allegedly real people are given unusual tasks, and their manipulations and stamina are dramatized; on reality "docusoaps" such as The Real World, Teen Mom, or the various Real Housewives franchises, previously unfamous people are followed around, their interactions, relationships, and especially conflicts presented as melodramatic documentary (Collins 90). In each the story is not just the game or the interpersonal dramas but also the "celebrification" (Rojek 186-87), visible in external coverage promoted by the shows' producers, as well as within the shows' dis- 
cursive environment. (Indeed, many of the "real housewives" have been shown marketing themselves over the course of a season, launching books, music careers, or skin-care lines on the basis of their newfound notoriety.) In Nick Couldry's terms, reality TV works by persistently, even ritualistically, telling the story of how ordinary people move from the periphery to the cultural center, becoming "media people" (85).

Another subgenre, dubbed "celebreality" by $\mathrm{VH} 1$, one of its main purveyors, makes ordinariness central in a different manner: reviving fading fame through the display of the ordinary lives of (mostly has-been) celebrities, on shows like Celebrity Fit Club, Dancing with the Stars, and Celebrity Survivor or programs built around figures like Scott Baio, Danny Bonaduce, Bobby Brown, and Tori Spelling. Filming ordinary lives (including moments of celebrity flatulence and bowel movements, discussion of sexual positions, and unusual uses of Preparation $\mathrm{H}$ ) is here the means of celebrity rehabilitation. To regain their fame, these celebrities purportedly show that they are real people, free of the artifice of the star system they are working so hard to reenter.

To a degree, then, reality TV_-financially driven, industrially produced, centrally controlled-has transformed celebrity culture by opening up unprecedented space for ordinary people to become celebrities. Perhaps more significant, it has accentuated the story of how a nobody becomes a somebody, pushing forward the rhetorical fantasy of democratized celebrity. Shows like America's Got Talent present celebrity as an elected status, in which "America" (as the audience is constantly addressed) votes on which ordinary person is most deserving of stardom. On shows like The Real World, celebrity appears as an equal-opportunity status that could land on anyone; on Celebrity Rehab, celebrity offers no protection from the quotidian struggles of body and psyche. For reality TV, ordinariness becomes a credential for star- dom, not its antithesis; the means of getting attention, not something that must be hidden.

Internet Celebrity: Anticelebrities, Do-It-Yourselfers, and Microcelebrities

The Internet, especially Web 2.0 phenomena such as YouTube, Myspace, and Facebookcollaborative, participatory sites "where users are increasingly involved in creating web content as well as consuming it" (Beer and Burrows) - has rapidly changed the dynamics of celebrity culture. In many ways, the Internet has simply extended the reach of the existing entertainment industry, which uses it as another marketing outlet, and expanded the business of gossip, since "rumors of bad behavior among celebrities likely travel faster online than any other kind of hearsay" (Grazian 203; see also Burns). But beyond the uses of new Web technologies for more of the familiar celebrity marketing and gossip, the Web has also generated a sort of bottom-up, do-it-yourself celebrity production process that is partly autonomous from its predecessors (Turner 54), since the "digital tools of self-publicity are increasingly available to ordinary people" (Bennett and Holmes 76). In the established Hollywood-based celebrity system, one has to navigate the tight gatekeeping structure, already tipped toward the young, beautiful, or talented; find, create, or wait for a break; get an agent, a job, a recording contract, and perhaps a publicist. The Internet drastically widens the pool of potential celebrities by lowering the entry barriers-a computer and a bit of moxie, and you've got a shot-and bypassing the tightly controlled publicity system and the tightly controlling middle people of Hollywood. In this arena, the fans are extremely active in the creation of celebrity: "viral" celebrity grows primarily through links forwarded from one person to another, reaction videos and blog postings, tagging, and so on (Sorgatz). Thus, many of the stories being generated, about celebrities 
and celebrity, are written outside the Hollywood star system.

Often this different celebrity environment means simply that the Internet is a launching pad for performers who manage to build an audience online that they then use to break into the off-line entertainment worldthe teen megastar Justin Bieber comes to mind here-becoming like more conventionally derived celebrities. Yet the Internet has also given rise to a distinctive celebrity culture, in which the audience celebrates its own star-making power: online celebrity is driven by the energy of "Hey, you guys, let's make somebody famous!"

The kinds of celebrities generated on the Internet tend to be quite different from the old image of the Hollywood star, yet in ways that once again promote the ordinary over the exceptional. One dominant type of Internet celebrity is the anticelebrity, a collective in-joke, in which the most unlikely candidate becomes the most celebrated, circulated star. These celebrities tend to be ordinary people-exhibiting no special talents or admirable qualities, offering no claims to greatness, and operating out of their living rooms - aside from a quirk that marks them as amateurs or outsiders. For instance, one of the earliest Web celebrities was a thirty-seven-year-old Turkish accordionist-journalist named Mahir Cagri, whose Web page became a sensation in 1999 (Gamson, "Web"). The site featured photos of the mustachioed Cagri in a teeny bathing suit, playing Ping-Pong, and with his accordion. It offered a welcome of "I Kiss You!!!!!" and frank proclamations such as "I like sex," some of which were apparently added by a Turkish hacker. Within months of his posting, his page views in the millions, Cagri was brought on a stateside tour, appeared on major talk shows, was profiled in Time, and was listed as one of Forbes's one hundred most influential people in the entertainment industry. Since then, this logic of the anticelebrity has driven much of Internet celebrity. For instance, Chris
Crocker's video blog about Britney Spears ("Leave Britney alone!" he rants tearfully) has been viewed more than 36 million times, received over 550,000 comments, and generated extensive media coverage and numerous parodies. Countless other examples emerge daily: the sexy philologist, the guy who started the "free hugs" movement, performers of unusual dances and weird lipsyncs, histrionic superfans, dancing babies. Until being pushed aside by Bieber and Lady Gaga, YouTube's mostviewed video was Charlie Bit My Finger, a family video of a young boy sticking his finger in his brother's mouth, which made both boys "unlikely international stars" (Moore).

A second dominant character in Internet celebrity is the self-made, do-it-yourself celebrity, who has pursued fame outside, despite, and sometimes in opposition to the established celebrity system. These stars tend to offer claims of extraordinariness, but their stories routinely assert that in the digital age anyone can game the system, create and brand an identity, and become a star. Tila Tequila, who went from Myspace popularity to reality TV stardom, is a prime example. She looks like a pinup, and indeed that is one of her many identities, but she got there by doing an end run around the Hollywood gatekeeping system. She is the queen of selfbranding, having successfully created and marketed herself without industry support (Trebay). ${ }^{3}$ Similarly, Jeffree Star, an androgynous, openly gay former club kid, makeup artist, model, and performer, became one of the biggest stars of Myspace, blogging and declaiming online and generating thousands of comments on each new posted photo; he is now a successful club music artist, among other things (Immediato). Star describes himself as "half super bitch and half mega cunt," "brazenly sexual and openly subversive," and the "consummate fame-sucking whore." He also notes his cultural significance: "He carries the torch as a self made celebrity," Star says, referring to himself in 
the celebrity third person. "Some celebrities are manufactured by the system. Others beat the system and manufacture themselves." For sale on his merchandise Web site are T-shirts that say, "Fuck me, I'm a celebrity."

A final variety of Internet celebrity, a close relative of the self-made star, is the microcelebrity, famous to a small community of fans who participate directly in producing the celebrity (Senft 25; Marwick and boyd). Some of what makes this fame micro is its scope; a new cliché suggests that soon we will all be famous to fifteen people (Momus). Another factor is the way the fame is generated: through the interactive dissemination of information about one's everyday life (Chaudhry; Thompson). This type of celebrity is made possible by online publishing and social-networking sites: anyone can blog about his or her everyday life to a potentially large audience, design a public profile with words and images, and instantaneously send "clever observations and ripostes targeted at dozens of adoring fans/friends," as one journalist and microcelebrity put it (Sorgatz). Self-publicity has become technologically easy, and the revelation of the ordinary self in everyday activity becomes a mechanism of attention gettingnothing else is needed. As one such star, the New York City self-promoter Julia Allison, put it, "In the past, I would have had to go through a reporter or a PR rep. Now we are all our own publicists. And we all have to learn the tricks" (qtd. in Tanz). Allison is now a "media personality," a "professional talking head" who has "made over 350 on-air appearances in the past year alone" ("Bio").

Internet celebrity culture has, then, made it easy for ordinary people to build an audience, bypassing the traditional celebrity industry; elevated the role of fans or audiences, turning them into powerful producers of celebrities, hyperaware of their star-making capacity; and moved to the forefront new celebrity characters and narratives that seem to defy the traditional celebrity system. Al- though the seeds were planted long ago, Weband reality-based culture have helped bring to fruition a significant trend in American celebrity: a rapid increase in the spectacle of ordinary people becoming celebrities and of celebrities being shown as entirely ordinary and a resurgence of the rhetorical claim that celebrity is available to anyone, no matter how unexceptional-in short, the lionization of the ordinary.

\section{Conclusion: Democratized Fame and Self-Surveillance}

On the one hand, one can see in these developments a further democratization of celebrity. Access to celebrity appears to have opened up radically, as ordinary people are pursued for entertainment and as publicity technologies not in control of Hollywood gatekeepers have become relatively easy and inexpensive to access. Celebrity cultivation has been at least partially decentralized, so that it is in the hands of many rather than a few. Through the Internet in particular, the power of audiences to create celebrity, not simply consume it, appears to have dramatically increased (Jenkins). Alternative visions of celebrity are thriving, many of them more egalitarian than their predecessors. Some are anti-industrial; some evade the commodification of celebrity; others celebrate the empowered self-commodifier; still others assert that ordinary lives can be, at least for a bit, worthy of attention.

On the other hand, it is easy to overestimate these changes. Even if much celebrity creation now takes place outside the entertainment centers of Los Angeles and New York, the control center of celebrity culture has hardly shifted. The interests of those with the capital to give celebrity its value remain primary. Web celebrity, for instance, still has nowhere near the social and commercial value of a good old-fashioned television appearance or studio contract. Internet users may be flexing 
their muscles at the moment of discovery, but cyberstars tend to try to convert their online celebrity into conventional Hollywood-ish currency. Moreover, the established entertainment industry has been quick to absorb celebrities whose fame is generated outside its quarters. In fact, the Internet takes much of the guesswork out of discovery, reducing risks and costs for major entertainment companies, since aspirants do the initial development and marketing. At the discursive level, too, the existing celebrity system is adept at absorbing these changes. The emergence of a vast layer of semiknown people whose celebrity has a "rapid rate of decay" can be mobilized to reinforce the value and distinction of those at the top of the celebrity hierarchy (Kurzman, Anderson, Key, Lee, Moloney, Silver, and Van Ryn 354). It is probably not coincidental that the elevation of ordinary celebrity has coincided with the popularizing of the notion of A-list and D-list celebrities (interestingly, one rarely hears mention of the $\mathrm{B}$ and $\mathrm{C}$ grades). The crowd of ordinaries-D-listers, wannabes, microcelebrities, YouTube and reality stars-often take their place as evidence that merited celebrity is rare, extraordinary, and justifiably more heavily rewarded (Palmer).

There are pulls and counterpulls at work, toward and away from a more egalitarian, popularly controlled celebrity system. Rather than being evidence of a democratized celebrity system, perhaps the ascent of the ordinary is significant for the everyday understandings of publicness that it both encourages and crystallizes. The ordinary turn in celebrity culture is ultimately part of a heightened consciousness of everyday life as a public performance-an increased expectation that we are being watched, a growing willingness to offer up private parts of the self to watchers known and unknown, and a hovering sense that perhaps the unwatched life is invalid or insufficient.

Many of us, with or without celebrity status, seem to be learning to do what Mark
Andrejevic has called "the work of being watched," induced by heightened surveillance. Expecting, as Couldry describes it, "any everyday activity legitimately to be put under surveillance and monitored for a huge unknown audience" (91), we are "auto-spies" who see ourselves through the constant "gaze of the other" (Andrejevic, "Visceral Literacy" 339). On Facebook and elsewhere, we design self-flattering profiles, post status updates, upload photos of ourselves and get tagged in others' uploads, labor to choose the right " 25 random things about me," which are, of course, not random at all. Video cameras are marketed with a one-touch-upload-toYouTube function. It is not so much that everyone gets fifteen minutes of fame or that anyone can be a star but that everyone already is a star: we ordinary people are growing accustomed to not just watching but also being constantly watched.

\section{NOTES}

1. Although fame has a cultural history reaching back many centuries (Braudy), the celebrity culture to which I refer is by definition contemporary, a phenomenon dependent on media industries capable of producing and disseminating images on a mass scale.

2. In a similar vein, Chris Rojek distinguishes between "achieved celebrity," which recognizes rare skills or talents (16), and "attributed celebrity," which arises from the work of "cultural intermediaries" (18).

3. Lisa Nakamura notes the racial meanings carried by Tequila's “"user generated' as well as self-made" construction of her own celebrity, which is "racialized as diasporic and polysexual" (1680).

\section{Works Cited}

Alberoni, Francesco. “The Powerless 'Elite': Theory and Sociological Research on the Phenomenon of the Stars." Sociology of Mass Communications: Selected Readings. Ed. Denis McQuail. Harmondsworth: Penguin, 1972. 75-98. Print.

Andrejevic, Mark. Reality TV: The Work of Being Watched. Lanham: Rowman, 2004. Print. 
_ . "Visceral Literacy: Reality TV, Savvy Viewers, and Auto-spies." Murray and Ouellette 321-42.

Beer, David, and Roger Burrows. "Sociology and, of and in Web 2.0." Sociological Research Online 12.5 (2007): n. pag. Web. 11 Jan. 2011.

Bennett, James, and Su Holmes. "The 'Place' of Television in Celebrity Studies." Celebrity Studies 1.1 (2010): 65-80. Print.

“Bio.” Julia Allison. N.p., n.d. Web. 11 Jan. 2011

Boorstin, Daniel J. The Image; or, What Happened to the American Dream. New York: Atheneum, 1962. Print.

Braudy, Leo. The Frenzy of Renown: Fame and Its History. New York: Oxford UP, 1986. Print.

Burns, Kelli S. Celeb 2.0: How Social Media Foster Our Fascination with Popular Culture. Santa Barbara: Praeger, 2009. Print.

Chaudhry, Lakshmi. "Mirror, Mirror on the Web." $\mathrm{Na}$ tion 29 Jan. 2007: 19-22. Print.

Collins, Sue. "Making the Most out of 15 Minutes: Reality TV's Dispensable Celebrity." Television and New Media 9.2 (2008): 87-110. Print.

Couldry, Nick. "Teaching Us to Fake It: The Ritualized Norms of Television's 'Reality' Games.” Murray and Ouellette 82-99.

deCordova, Richard. Picture Personalities: The Emergence of the Star System in America. Urbana: U of Illinois P, 1990. Print.

Dyer, Richard. Stars. London: British Film Inst., Educ. Advisory Service, 1979. Print.

Gabler, Neal. Toward a New Definition of Celebrity. Los Angeles: Norman Lear Center, U of Southern California Annenberg School of Communication, 2001. Print.

Gamson, Joshua. Claims to Fame: Celebrity in Contemporary America. Berkeley: U of California P, 1994. Print.

. "The Web of Celebrity." American Prospect 11 Sept. 2000: 40-41. Print.

Grazian, David. Mix It Up: Popular Culture, Mass Media, and Society. New York: Norton, 2010. Print.

Holmes, Su. "It's a Jungle Out There! Playing the Game of Fame in Celebrity Reality TV." Framing Celebrity: New Directions in Celebrity Culture. Ed. Holmes and Sean Redmond. London: Routledge, 2006. 45-66. Print.

Immediato, Linda. "Jeffree Star, the Fairest One of All." LA Weekly. LA Weekly, 9 May 2007. Web. 11 Jan. 2011.

Jenkins, Henry. Convergence Culture: Where Old and New Media Collide. New York: New York UP, 2006. Print.
Kurzman, Charles, Chelise Anderson, Clinton Key, Youn Ok Lee, Mairead Moloney, Alexis Silver, and Maria W. Van Ryn. “Celebrity Status.” Sociological Theory 25.4 (2007): 347-67. Print.

Marwick, Alice E., and danah boyd. "I Tweet Honestly, I Tweet Passionately: Twitter Users, Context Collapse, and the Imagined Audience." New Media and Society 13.1 (2010): 114-33. Print.

Mole, Tom. "Hypertrophic Celebrity." M/C Journal 7.5 (2004): n. pag. Web. 11 Jan. 2011.

Momus. "Pop Stars? Nein Danke!” Momus: Becoming a Unit. Momus, n.d. Web. 11 Jan. 2011.

Moore, Matthew. "Finger-Biting Brothers Become YouTube Hit." The Telegraph. Telegraph Media Group, 5 Dec. 2008. Web. 20 Nov. 2009.

Murray, Susan, and Laurie Ouellette, eds. Reality TV: Remaking Television Culture. 2nd ed. New York: New York UP, 2009. Print.

Nakamura, Lisa. “Cyberrace.” PMLA 123.5 (2008): 1673 82. Print.

Palmer, Gareth. "The Undead: Life on the D-List." Westminster Papers in Communication and Culture 2.2 (2005): 37-53. Print.

Raphael, Chad. "The Political Economic Origins of RealiTV." Murray and Ouellette 123-40.

Rojek, Chris. Celebrity. London: Reaktion, 2001. Print.

Schickel, Richard. Intimate Strangers: The Culture of Celebrity. Garden City: Doubleday, 1985. Print.

Senft, Theresa M. Camgirls: Celebrity and Community in the Age of Social Networks. New York: Lang, 2008. Print.

Sorgatz, Rex. "The Microfame Game and the New Rules of Internet Celebrity." New York Magazine. New York Media, 17 June 2008. Web. 11 Jan. 2011.

Star, Jeffree. "It's Jeffree, Bitch! on Myspace." Myspace. Myspace, n.d. Web. 11 Jan. 2011.

Tanz, Jason. "Internet Famous: Julia Allison and the Secrets of Self-Promotion." Wired. Condé Nast Digital, 15 July 2008. Web. 11 Jan. 2011.

Thompson, Clive. "The Age of Microcelebrity: Why Everyone's a Little Brad Pitt.” Wired 27 Nov. 2007: n. pag. Web. 11 Jan. 2011.

Trebay, Guy. "She’s Famous (and So Can You).” New York Times. New York Times, 28 Oct. 2007. Web. 12 Aug. 2011.

Turner, Graeme. Understanding Celebrity. London: SAGE, 2004. Print.

Warhol, Andy, and Bob Colacello. Andy Warhol's Exposures. New York: Grosset, 1979. Print. 